\title{
ECOLOGICAL DISTRIBUTION AND POPULATION STRUCTURE OF Acantholobulus schmitti (RATHBUN, 1930) (CRUSTACEA, DECAPODA, XANTHOIDEA) ON THE SOUTHEASTERN BRAZILIAN COAST
}

\author{
Vivian Fransozo ${ }^{1}$, Thiago Elias da Silva ${ }^{2, *}$, Patrícia Bianca Fumis ${ }^{2}$, \\ Giovana Bertini ${ }^{3}$ and Paloma Aparecida de Lima ${ }^{2}$ \\ Universidade Estadual do Sudoeste da Bahia - UESB \\ Departamento de Ciências Naturais \\ (Campus de Vitória da Conquista, 45031-900 Vitória da Conquista, BA, Brasil) \\ Universidade Estadual Paulista "Julio de Mesquita Filho" - UNESP \\ Instituto de Biociências de Botucatu, Departamento de Zoologia \\ (Distrito de Rubião Júnior, S/N, 18618-970, Botucatu, SP, Brasil) \\ Universidade Estadual Paulista "Julio de Mesquita Filho" - UNESP \\ Campus Registro \\ (Rua Nelson Brihi Badur, 430, 11900-000, Registro, SP, Brasil) \\ *Corresponding author: thiago.el.silva@gmail.com
}

\begin{abstract}
A B S T R A C T
This investigation analyzed the ecological distribution and population structure of A. schmitti on the southeastern coast of Brazil. Crabs were sampled monthly from January 1998 to December 1999 at the following bays: Ubatumirim (UBM), Ubatuba (UBA) and Mar Virado (MV). Water and sediment samples were also collected from all sampling sites for an analysis of environmental factors. Acantholobus schmitti was most abundant at UBM (224), followed by UBA (154) and MV (23) but its abundance showed no association with the environmental factors analyzed. The low abundance of these crabs in MV may be due to the high wave action that moved biodetritic material accumulated on the bottom and frequently removed small crabs from their sheltered positions among the shell fragments. The individuals captured included 269 males and 132 females, of which only 4 specimens were brooding females. Juvenile recruitment occurred throughout the year, but was less intense in the spring. The major abundance of individuals as well as of ovigerous females occurred during 1999, when the entrance of the South Atlantic Central Waters (SACW) was stronger than in previous year. This environmental influence could be the main factor modulating this population.
\end{abstract}

\section{RESUMO}

Os objetivos deste estudo foram analisar a distribuição ecológica e a estrutura populacional de A. schmitti no litoral sudeste brasileiro. Os caranguejos foram coletados, mensalmente, de janeiro de 1998 a dezembro de 1999 nas enseadas: Ubatumirim (UBM), Ubatuba (UBA) e Mar Virado (MV), onde também foram obtidas amostras de água e sedimento para análise dos fatores ambientais. A maior abundância de A. schmitti foi verificada em UBM (224), seguida por UBA (154) e MV (23) e não apresentou associação com os fatores ambientais analisados. O motivo da baixa abundância desses caranguejos em MV pode ser a alta ação de ondas que movimenta o material biodetrítico acumulado no fundo e, frequentemente, remove pequenos caranguejos de seus abrigos entre fragmentos de conchas. Os indivíduos foram 269 machos e 132 fêmeas, das quais apenas 4 eram ovígeras. O recrutamento juvenil ocorreu o ano todo, sendo menos intenso na primavera. A maior abundância de indivíduos, bem como as fêmeas ovígeras, ocorreu em 1999, quando a entrada da Água Central do Atlântico Sul (ACAS) foi mais intensa do que no ano anterior. Esta influência ambiental pode ser o principal fator modulador para esta população.

Descriptors: Environmental factors, Panopeidae, Abundance, Water mass. Descritores: Fatores ambientais, Panopeidae, Abundância, Massas de água. 


\section{INTRODUCTION}

Variations in the abundance and distribution of crabs both in space and time are associated with a series of environmental factors that can determine the presence of a species in a certain place or its exclusion from it (MANTELATTO et al., 1995a; MANTELATTO; FRANSOZO, 1999a). Water temperature, salinity, organic matter content and sediment texture should be considered fundamental factors in ecologic studies (BUCHANAN; STONER, 1988) considering that they modulate both primary and secondary sea productivity and determine the particular features of each locale.

Due to the oceanic extension and complex interactions between the environmental and biotic factors, the distributional patterns of benthic populations are not easily comprehended (SHIRLEY et al., 1990). Population studies in small areas such as bays and inlets can thus contribute to the understanding of some of the interactions between invertebrates and environmental factors (MANTELATTO et al., 1995a; BRAGA et al., 2007). Intensive studies are needed in some regions of the southeastern Brazilian littoral, such as Ubatuba, where an intense, haphazard expansion of tourism has occurred that can affect local marine ecosystems, especially through factors which influence the development of invertebrate populations (MANTELATTO et al. 1995b).

The northern coast of the state of São Paulo (in the southeast of Brazil) is characterized by a great number of bays and an irregular coastline. This topography is due to the close proximity of the shoreline to the southward-facing escarpment of the Serra do Mar (MAHIQUES, 1995). These features resulted in the formation of microhabitats that permit the development and establishment of the marine biota (NEGREIROS-FRANSOZO et al., 1991).

The southeastern Brazilian coast has, therefore, been the target of a series of studies related to the species richness, abundance and diversity of decapod crustaceans. The following deserve mention: Fransozo et al. (1992, 1998), Negreiros-Fransozo et al. (1992, 1997, 1999), Pires-Vanin (1992), Hebling et al. (1994), Sumida; Pires-Vanin (1997), NegreirosFransozo and Nakagaki (1998), Lavrado et al. (2000), Mantelatto; Fransozo (2000), Costa et al. (2000), Bertini et al. (2004, 2010), Bertini; Fransozo (2004), and De Léo and Pires-Vanin (2006).

Xanthoid crabs play an important ecologic role in marine ecosystems due to their abundance and the predatory behavior of some of their species (COELHO; COELHO-FILHO, 1994). Acantholobulus schmitti (Rathbun, 1930) is a species of small crab occurring in the western Atlantic from northeastern Brazil to Uruguay (MELO, 1996). It is commonly found with fishes, shrimps and other invertebrates obtained during artisanal fishery activities (by-catch). Such activity is considered predatory and the cause of benthic community destabilization (RUFFINO; CASTELLO, 1992/1993; BRANCO; FRACASSO, 2004).

This investigation aimed to analyze the following ecological aspects of the xanthoid crab $A$. schmitti: spatio-temporal distributions in relation to environmental factors (temperature, salinity and sediment characteristics), seasonality, and population structure (sex-ratio, size distribution frequency and recruitment period). Since studies of the unconsolidated subtidal zone involving xanthoids are scarce, the results of this study will serve as an important tool for developing conservation and environmental management projects.

\section{Material ANd Method}

Study Area

The Ubatuba region is characterized by innumerable spurs of the Serra do Mar that result in an extremely indented coastline (AB'SABER, 1955). The exchange of water and sediment between the coastal region and the adjacent shelf is very limited (MAHIQUES, 1995). This region is affected by three water masses: Coastal Water (CW: temperature > $20^{\circ} \mathrm{C}$; salinity <36), Tropical Water (TW: temperature $>20^{\circ} \mathrm{C}$; salinity > 36) and South Atlantic Central Water (SACW: temperature $<18^{\circ} \mathrm{C}$; salinity $<36$; Nitrogen:Phosphorus = 16:1) (CASTRO-FILHO et al. 1987; ODEBRECHT; CASTELLO 2001). During summer, the SACW penetrates into the bottom layer of the coastal region and forms a thermocline over the inner shelf at depths of 10 to $15 \mathrm{~m}$. During the winter, the SACW retreats to the shelf break and is replaced by the $\mathrm{CW}$. As a result, no stratification is present over the inner shelf during the winter months (PIRESVANIN, 1992; PIRES-VANIN; MATSUURA 1993). The sediment is composed mainly of fine and very fine sand and silt and clay, given the sluggish water movement within the bay and between the bay and the adjacent continental shelf (MAHIQUES et al., 1998).

\section{Crab Sampling and Environmental Features}

Crabs were collected monthly, from January 1998 to December 1999, in the bays: Ubatumirim (UBM), Ubatuba (UBA) and Mar Virado (MV) on the northern coast of the State of São Paulo, Brazil. Six transects were established in each bay, three in areas protected from wave action (with depths of 5, 7.5 and $10 \mathrm{~m})$ and three in exposed areas $(10,15$ and $20 \mathrm{~m})$ (Fig. 1). 


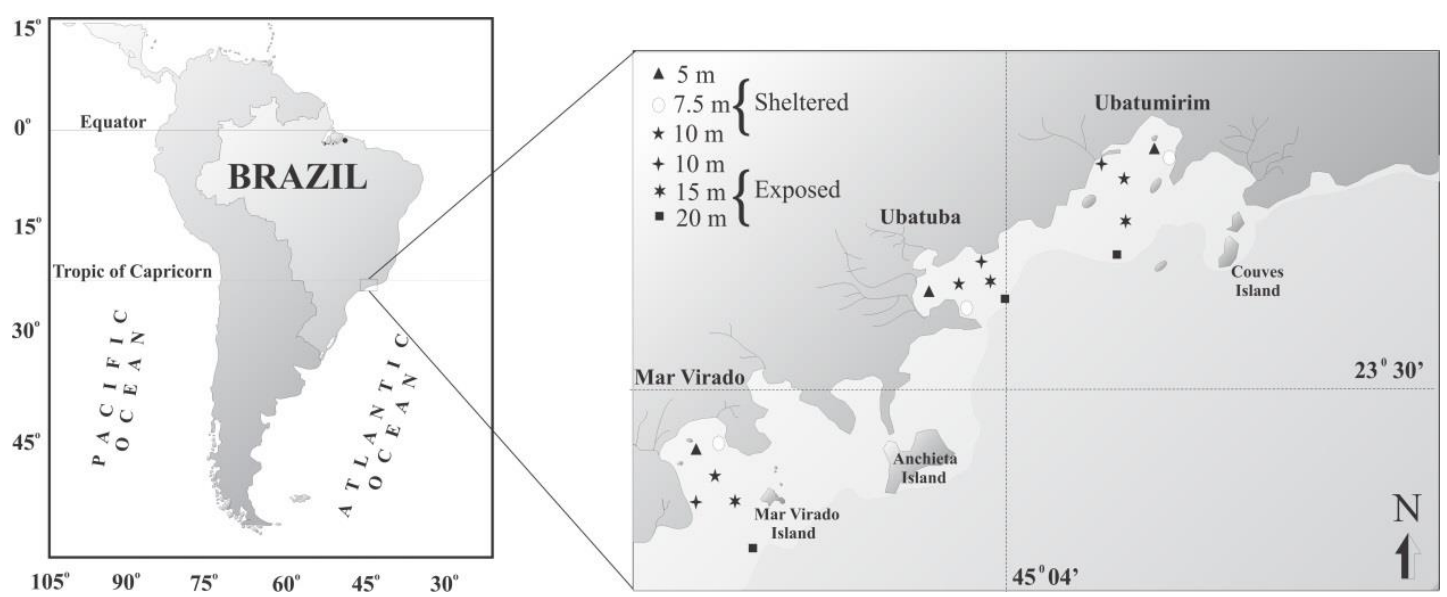

Fig. 1. Ubatuba region map, northern coast of the State of São Paulo, Brazil, indicating the bays, areas and transects studied in this region.

Sampling was carried out using a shrimp fishery boat equipped with a double-rig consisting of a main net body with a $20 \mathrm{~mm}$ mesh and a terminal cod with a $15 \mathrm{~mm}$ mesh. Trawls were carried out for 30 min each, sampling a total area of approximately $18,000 \mathrm{~m}^{2}$.

The crabs were identified according to Melo (1996), their sex was determined by abdominal morphology and their major carapace width $(\mathrm{CW})$ was measured using a caliper $(0.01 \mathrm{~mm})$. All specimens were classified into the following demographic groups: $\mathrm{JM}=$ juvenile males, $\mathrm{AM}=$ adult males, $\mathrm{JF}=$ juvenile females, $\mathrm{AF}=$ adult females and $\mathrm{OF}=$ ovigerous females. The differentiation between adults and juveniles was made in accordance with Fumis et al. (2007), who considered all specimens with CW greater than $6.1 \mathrm{~mm}$. (males) and $4.8 \mathrm{~mm}$ (females) to be adults.

Salinity (\%o) and temperature $\left({ }^{\circ} \mathrm{C}\right)$ were recorded from surface- and bottom-water samples obtained with a Nansen bottle at the midpoint of each transect. Depth was measured for each transect using an ecobathymeter coupled with a GPS. Substrate samples were collected from the midpoint of each transect, using a $0.06 \mathrm{~m}^{2}$ Van Veen grab, and were used to analyze organic-matter content and granulometric composition. Each sample was placed in a plastic bag, tagged, and frozen to minimize the decomposition of organic matter.

The sediment for granulometric analysis was separated into two samples of $50 \mathrm{~g}$ each. After that, $250 \mathrm{ml}$ of $\mathrm{NaOH}$ solution $(0.2 \mathrm{~N})$ was added to suspend silt+clay. The subsamples were washed using a sieve (mesh size $=0.063 \mathrm{~mm}$ ) passing only the silt+clay fraction. The remaining sediment was dried and passed through a graduated sieve in accordance with Wentworth's (1922) method.
Measures of central tendency $(\varphi)$ were used to determine which of the grain-size fractions was most frequent in the sediment on the basis of their percentages at each transect. These values were calculated according to the graphical depiction of the cumulative frequency-distribution curves of the sediments based on the $\varphi$ scale $\left(\varphi=-\log _{2}\right.$ of the diameter of the grain in $\mathrm{mm}$ ) and later converted to the American scale in $\mathrm{mm}$ according to the formula $\mathrm{DM}=$ $\varphi_{16}+\varphi_{50}+\varphi_{84} / 3$ (TUCKER, 1988). The degree of sediment sorting was calculated by the formula GS = $\left(\varphi_{16}+\varphi_{84}\right) / 4+\left(\varphi_{95}+\varphi_{5}\right) / 6.6$, according to Suguio (1973).

All procedures for sediment analysis followed the protocols of Håkanson and Jansson (1983) and Tucker (1988).

The organic-matter content of the sediment was estimated as the difference between the initial and final ash-free dry weights of three sub-samples $\left(10 \mathrm{~g}\right.$ each) incinerated in porcelain crucibles at $500^{\circ} \mathrm{C}$ for $3 \mathrm{~h}$.

\section{Data Analyses}

The data did not pass tests for normality (Shapiro-Wilk test) or homoscedasticity (Levene test) but non-parametric analyses were performed. The bottom temperature (BT), surface temperature (ST), salinity (S), and organic matter (MO) were compared among bays, transects and annual seasons (i.e., summer, January to March; autumn, April to June; winter, July to September; and spring from October to December) by means of the Kruskal-Wallis statistical test. The Mann-Whitney test was used to test the values of BT, ST, S and MO between the areas (sheltered or exposed). The association between 
environmental factors and species abundance was evaluated by means of simple linear regression.

The abundance of $A$. schmitti was compared for its spatial and temporal distributions using the Kruskal-Wallis test, followed by Dunn's a posteriori test (for transects, bays and seasons) and the MannWhitney test (for areas) (ZAR, 1996). The significance level adopted here was $\mathrm{p}<0.05$.

The sex ratio was estimated as the number of females divided by the number of males in the population, which was compared by means of a binomial test for deviation from the 1:1 pattern $(\mathrm{p}<$ 0.05) (WILSON; HARDY, 2002; BAEZA et al., 2010). The identification of modes in the size classes was determined by means of Peakfit version 4.12 (SEA SOLVE SOFTWARE INC., 1999-2003) and the comparison of the mean size between the sexes was tested by the Mann-Whitney test.

\section{RESULTS}

Environmental Factors and the Ecologic Distribution of A. schmitti

The BT, ST and S values had already been reported by Costa et al. (2007), Costa and Fransozo (2004), and Bertini et al. (2001), whose studies were undertaken at the same sampling sites and times as the present study. The mean values for bottom and surface temperatures did not differ significantly between bays, but those values differed in each bay according to season, being lowest during the winter and spring for ST and BT, respectively (Fig. 2). The highest $\mathrm{S}$ values were registered in transects at depths of $20 \mathrm{~m}$ and the lowest in transects at 5 and $7.5 \mathrm{~m}$. The statistical results comparing the environmental variables (in relation to the bays, areas, transects and seasons) are presented in Table 1.

The sediment analyses indicated a trend to an increase in the phi values from north to south (i.e., the grain diameters of the sediments diminish), with the mean values at UBM, UBA and MV being 3.8, 4.4 and 5.5, respectively. The mean values in all the bays studied were measured on transects $20 \mathrm{~m}$ deep and generally in the exposed areas. The bays with higher values of MO were UBA $(5.48 \%)$, followed by MV (4.94\%) and UBM (3.61\%) (Fig. 3).

A total of 401 individuals of $A$. schmitti were obtained. We found a trend toward a higher number of individuals in salinities between 33.5 and 36.2. In the UBM and UBA bays there was a concentration of specimens in phi values from 4.11 to 3.46 . However, the linear regressions did not indicate any relationship between the abundance of crabs and environmental factors. The size-frequency distribution of specimens in each size class is shown in Figure 4.
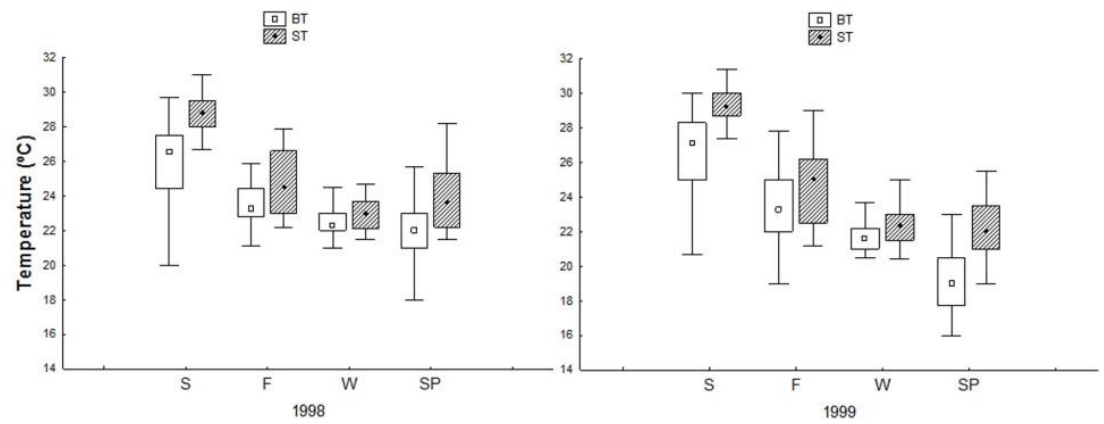

Fig. 2. Box-Plot graphs with data on the median, percentage, minimum and maximum of the bottom (BT) and surface (ST) temperature values in each season during 1998 and 1999. $\mathrm{S}=$ summer, $\mathrm{F}=$ fall, $\mathrm{W}=$ winter and $\mathrm{SP}=$ spring.

Table 1. Results of the Kruskal-Wallis (H) and Mann-Whitney (U) tests (comparison of BT, ST, S and OM among bays, areas, transects and seasons).

\begin{tabular}{|c|c|c|c|c|c|}
\hline & Year & $\begin{array}{c}\text { B T } \\
\text { DF / Test value }\end{array}$ & $\begin{array}{c}\text { ST } \\
\text { DF / Test value }\end{array}$ & $\begin{array}{c}\mathbf{S} \\
\text { DF / Test value }\end{array}$ & $\begin{array}{c}\text { \%OM } \\
\text { DF / Test value }\end{array}$ \\
\hline \multirow{2}{*}{ Bay } & 1998 & $2 / \mathrm{H}=1.45$ & $2 / \mathrm{H}=1.82$ & $2 / \mathrm{H}=0.60$ & $2 / \mathrm{H}=11.30^{*}$ \\
\hline & 1999 & $2 / \mathrm{H}=0.39$ & $2 / \mathrm{H}=0.71$ & $2 / \mathrm{H}=22.53^{*}$ & $2 / \mathrm{H}=11.95^{*}$ \\
\hline \multirow{2}{*}{ Area } & 1998 & $\mathrm{U}=3958.50^{*}$ & $\mathrm{U}=4926.00^{*}$ & $\mathrm{U}=4834.00^{*}$ & $\mathrm{U}=3370.50^{*}$ \\
\hline & 1999 & $\mathrm{U}=4284.50^{*}$ & $\mathrm{U}=4969.50$ & $\mathrm{U}=4316.00^{*}$ & $\mathrm{U}=4500.00^{*}$ \\
\hline \multirow{2}{*}{ Transects } & 1998 & $5 / \mathrm{H}=47.45^{*}$ & $5 / \mathrm{H}=6.55$ & $5 / \mathrm{H}=8.86$ & $5 / \mathrm{H}=46.70^{*}$ \\
\hline & 1999 & $5 / \mathrm{H}=24.25^{*}$ & $5 / \mathrm{H}=5.95$ & $5 / \mathrm{H}=18.55^{*}$ & $5 / \mathrm{H}=17.43^{*}$ \\
\hline \multirow{2}{*}{ Year seasons } & 1998 & $3 / \mathrm{H}=65.47 *$ & $3 / \mathrm{H}=133.55^{*}$ & $3 / \mathrm{H}=58.62 *$ & $3 / \mathrm{H}=21.24 *$ \\
\hline & 1999 & $3 / \mathrm{H}=135.42 *$ & $3 / \mathrm{H}=140.76^{*}$ & $3 / \mathrm{H}=36.23^{*}$ & $3 / \mathrm{H}=24.44 *$ \\
\hline
\end{tabular}




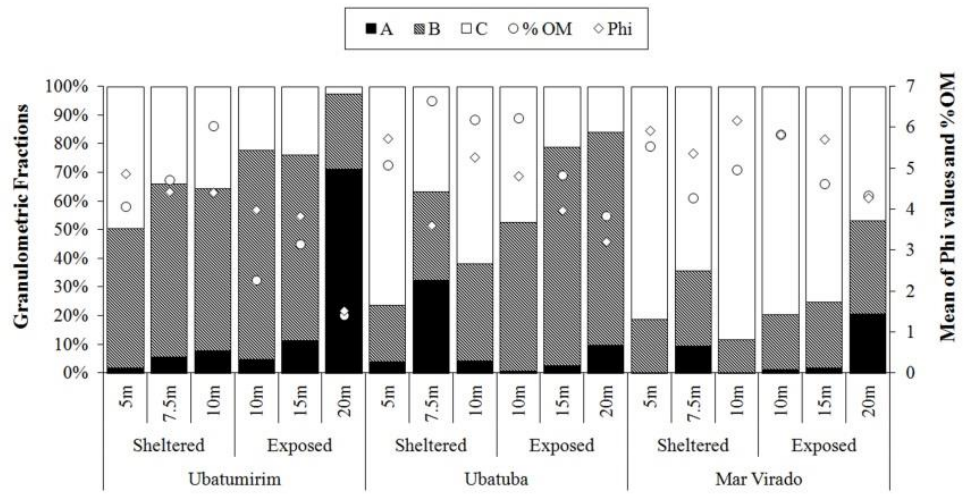

Fig. 3. Representation of the results from the sediment analyses. The columns show the granulometric fractions obtained from January, 1998 to December, 1999. (A = median sand + coarse sand + gravel, $\mathrm{B}=$ fine sand + very fine sand and $\mathrm{C}=$ silt + clay; circle $=$ mean values of phi and square $=$ mean values of $\% \mathrm{OM}$ in each sampled transect.
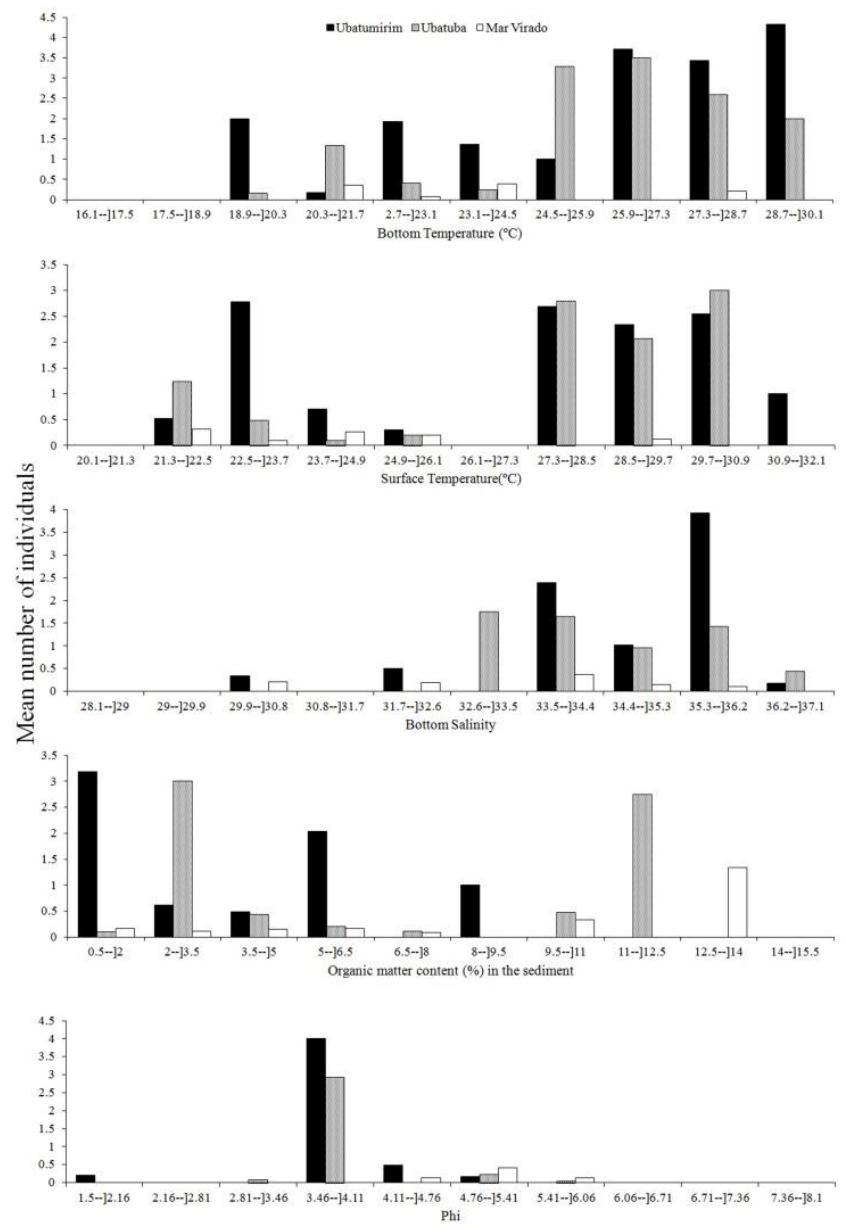

Fig. 4. Acantholobulus schmitti. Total abundance of specimens, distributed according to environmental factors classes, at UBM, UBA and MV from January 1998 to December 1999. 
The Kruskal-Wallis test showed differences in the distribution of specimens among the bays and transects $(\mathrm{p}=0.01)$, with the lowest abundance verified in MV $(\mathrm{N}=23)$, followed by UBA $(\mathrm{N}=154)$ and UBM $(\mathrm{N}=224)$. The exposed transects at UBM and UBA, with depths of $10 \mathrm{~m}$ and $7.5 \mathrm{~m}$, respectively, had higher abundances of crabs than the others (Dunn's a posteriori test). The abundance of individuals did not differ significantly between exposed and sheltered sites. Considered as the year station no significant differences were found in the abundance of individuals $(\mathrm{p}=0.307)$ (Table 2). The individual abundances on each transect and in each area and bay are shown in Figure 5.

Table 2. Acantholobulus schmitti. Results of the Kruskal-Wallis (H) and Mann-Whitney (U) tests (comparison of the abundance of crabs among bays, areas, transects and seasons).

\begin{tabular}{cccc}
\hline \hline Source & Test & DF & p \\
\hline Bays & $\mathrm{H}=8.37^{*}$ & 2 & $0.01^{*}$ \\
Areas & $\mathrm{U}=22969.50$ & 1 & 0.78 \\
Transects & $\mathrm{H}=29.68^{*}$ & 5 & $0.00^{*}$ \\
Year seasons & $\mathrm{H}=3.60$ & 3 & 0.3 \\
\hline
\end{tabular}

$\mathrm{DF}=$ degrees of freedom, ${ }^{*} \mathrm{p}<0.05$

Population Structure

The abundances of specimens by each demographic group were $219 \mathrm{JM}, 50 \mathrm{AM}, 95 \mathrm{JF}$ and $37 \mathrm{AF}$, of which only 4 were OF. The sex ratio deviated significantly from $1: 1(\mathrm{p}<0.01)$ in the majority of the size classes and the total number of individuals. The sex ratio was similar to $1: 1$ only in the CW size classes 3--]4; 8--]9 and 9--]10 mm (Table $3)$.

The mean size of the specimens differed significantly between the sexes, being $4.92 \mathrm{~mm}$ $( \pm 1.26)$ for males and $3.4 \mathrm{~mm}( \pm 1.36)$ for females $(\mathrm{p}<0.01)$. The size-class distribution of specimens exhibits a bimodal distribution for both sexes, with modal peaks of 4--]5 and 6--]7 for males and 3--]4 and 8--]9 for females (Fig. 6).

There was a predominance of juveniles in all seasons. The highest recruitment period occurred from summer to winter in UBM and UBA, with the peak of abundance in MV during autumn. The lowest abundance of individuals occurred in spring for all the bays studied. Ovigerous females were obtained only in MV, including one specimen in autumn and 3 in winter. All were found in 1999 on transects at depths of $7.5,15$ and $20 \mathrm{~m}$, the respective numbers of specimens being 2, 1 and 1 (Fig. 7).

\section{DisCUSSION}

Even though no significant relationship was found between the abundance of specimens and the phi values, the major occurrence of crabs in UBM could be influenced by the heterogeneous values of such factors. These variations in sediment composition could indicate greater availability of refuges to the species (BERTINI et al., 2004; BRAGA et al., 2005). Furthermore, large amounts of algae, leaves, small pieces of wood and sometimes tree branches were found in this sampling site that originated from the adjacent forest and increase the chances of these crabs finding refuge.

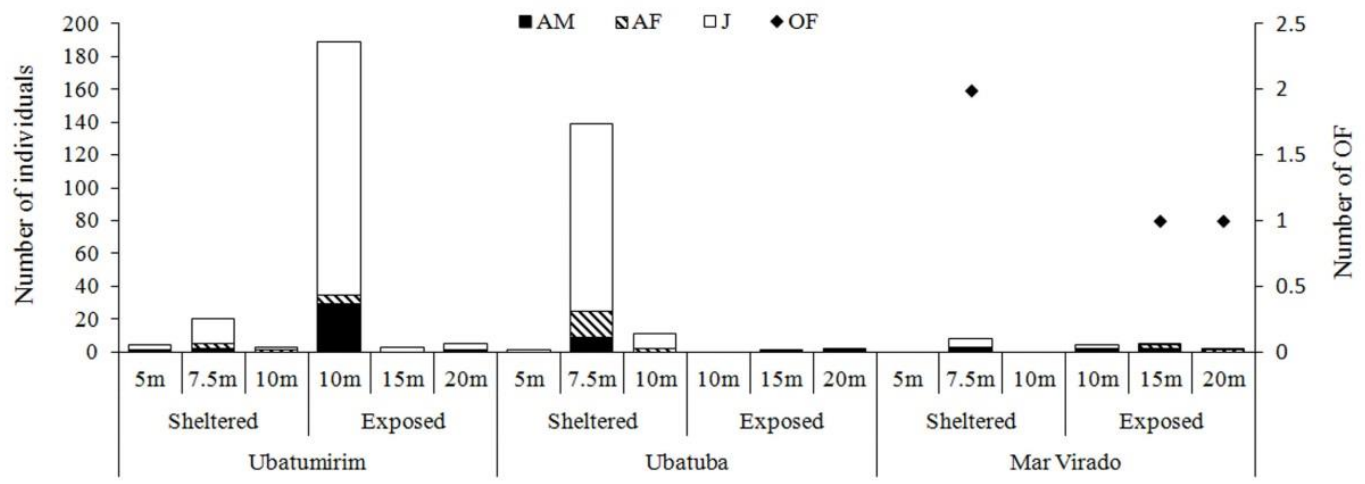

Fig. 5. Acantholobulus schmitti. Spatial distribution of specimens by transect, areas and bays, from January, 1998 to December, 1999. $\mathrm{AM}=$ Adult males; $\mathrm{AF}=$ Adult females; $\mathrm{J}=$ Juveniles and $\mathrm{OF}=$ Ovigerous females. 
Table 3. Acantholobulus schmitti. Sex ratio and demographic group size-class distributions.

\begin{tabular}{|c|c|c|c|c|c|c|c|c|}
\hline \multirow{2}{*}{ Size Classes } & \multicolumn{3}{|c|}{ Males } & \multicolumn{3}{|c|}{ Females } & \multirow{2}{*}{ Ratio (M:F) } & \multirow{2}{*}{ Binomial test value / $\mathrm{p}$} \\
\hline & JM & $\mathrm{AM}$ & Total & JF & $\mathrm{AF}$ & Total & & \\
\hline 2--]3 & 13 & 0 & 13 & 4 & 0 & 4 & $1.0: 0.3$ & $0.78 / 0.03^{*}$ \\
\hline 3--]4 & 44 & 0 & 44 & 54 & 0 & 54 & $1.0: 1.2$ & $0.45 / 0.31$ \\
\hline 4--]5 & 87 & 0 & 87 & 37 & 7 & 44 & $1.0: 0.5$ & $0.66 / 0.00^{*}$ \\
\hline 5--]6 & 60 & 0 & 60 & 0 & 10 & 10 & $1.0: 0.2$ & $0.86 / 0.00^{*}$ \\
\hline $6--17$ & 15 & 30 & 45 & 0 & 8 & 8 & $1.0: 0.8$ & $0.85 / 0.00^{*}$ \\
\hline 7--]8 & 0 & 14 & 14 & 0 & 1 & 1 & 1.0:0.1 & $0.95 / 0.00 *$ \\
\hline 8--]9 & 0 & 3 & 3 & 0 & 8 & 8 & $1.0: 2.7$ & $0.32 / 0.18$ \\
\hline 9--]10 & 0 & 3 & 3 & 0 & 3 & 3 & $1.0: 1.0$ & $0.57 / 0.84$ \\
\hline Total & 219 & 50 & 269 & 95 & 37 & 132 & $1.0: 0.5$ & $0.67 / 0.00^{*}$ \\
\hline
\end{tabular}

$\mathrm{JM}=$ Juvenile males; $\mathrm{AM}=$ Adult males; $\mathrm{JF}=$ Juvenile females; $\mathrm{AF}=$ Adult females. $\left(*_{\mathrm{p}}^{\mathrm{p}}<0.05\right)$

Males $\$$ Females

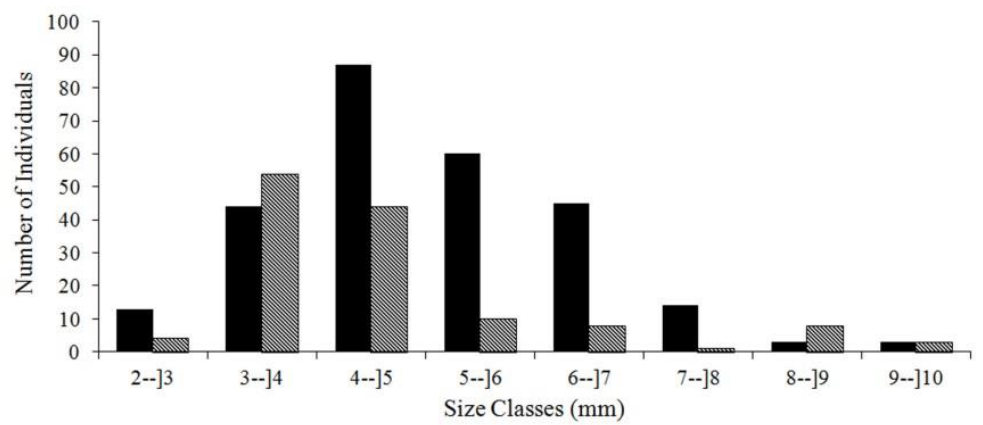

Fig. 6. Acantholobulus schmitti. Total specimens obtained distributed in size classes.

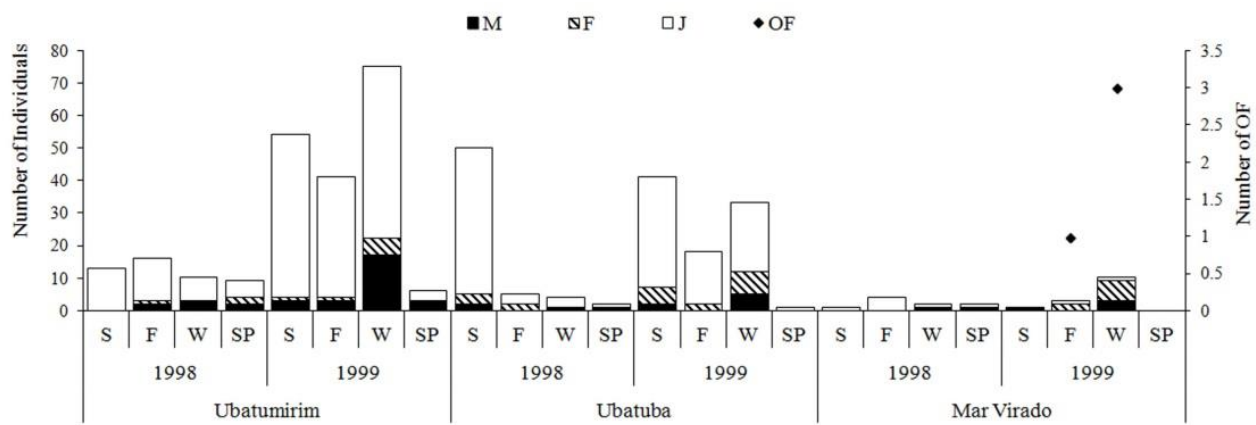

Fig. 7. Acantholobulus schmitti. Temporal distribution of demographic groups in each sampled bay from January 1998 to December 1999. $\mathrm{M}=$ adult males, $\mathrm{F}=$ adult females, $\mathrm{J}=$ juveniles, OF = ovigerous females, $\mathrm{S}=$ summer, $\mathrm{A}=$ autumn, $\mathrm{W}=$ winter and $\mathrm{SP}=$ spring.

According to Melo (1996), A. schmitti is associated with both consolidated and nonconsolidated substrates. This could also be why there was no correlation between abundance and environmental factors. Thus this crab species could be easily moved and captured by trawl nets. This same mechanism could explain the high presence of juvenile crabs, as they are most vulnerable to wave action and could be dislodged more easily. Another reason for this differential abundance as well as for the lack of correlation of abundance with the environmental factors investigated could be the wide ecological 
tolerance of A. schmitti, as this species can be found in various marine substrates (rocks, sediments and others).

The great differences in individual abundances between the bays could be due to the cryptic habits of such crab species. The MV bay is less protected from the movement of water masses than the other two (UBA and UBM) as it has no natural barriers - such as islands - to shield it. The water movement could dislodge the benthic community (CASTRO-FILHO et al., 1987), thus removing the biodetritic material used by this species for protection and as refuge from predators.

Other authors also found lower numbers of specimens of other decapod species in MV: Bertini et al. (2001) for the crabs Persephona punctata and $P$. lichtensteinii, and Costa and Fransozo (2004) for the penaeidean shrimp Rimapenaeus constrictus. Those authors attributed the low abundance of these decapods to the predominance of silt+clay in the sediment of this bay. However, the lack of correlation of the abundance of A. schmitti to this environmental factor suggests that granulometric characteristics do not determine the distribution of this species.

The sex-ratio distribution within size classes indicates the existence of a pattern such as the "standard" proposed by Wenner (1972), who described species with males occupying larger size classes than females. The "standard pattern" is common for crustaceans, according to this same author. Such sex-ratio differences can be affected by a series of factors, including longevity, mortality and differential growth rates between the sexes (WENNER, 1972; WINGET et al., 1974; HALEY, 1979; HARTNOLL, 1982). The sex ratio of $A$. schmitti favoring males was also found by Alves et al. (2012) in the rocky subtidal zone of Vitória Archipelago on the southeastern coast of Brazil.

The bimodal pattern observed for A. schmitti in the size-class frequency distribution could suggest the occurrence of two age groups in this population, most likely due to recruitment pulses or differential mortality rates, which could be influenced by accentuated environmental variations. Additionally, the distinct behavior of each of such species within each demographic group could be an influencing factor in this case, as mentioned by Díaz and Conde (1989) for Aratus pisonii.

Larger sizes occurring in males represents a sexual dimorphism, which is most likely related to the fact that males show a prolonged growth period, sometimes with major molt increments. By contrast, females should devote more energy to reproduction than to growth because the production of oocytes needs more energetic resources than the production of spermatozoa (ALUNNO-BRUSCIA; SAINT-MARIE,
1998). This assumption is reinforced by Fumis et al. (2007), who concluded that males of $A$. schmitti attain their morphologic maturity at larger sizes than females. Nevertheless, studies of individual growth and reproductive investment within populations could verify this hypothesis.

The same type of sexual dimorphism has also been shown to exist in other brachyuran species: Hepatus pudibundus by Mantelatto et al. (1995b), Callinectes ornatus by Mantelatto and Fransozo (1999b), Uca burgesi by Benetti and NegreirosFransozo (2004) and Uca rapax by Castiglioni and Negreiros-Fransozo (2005). The males of most crab species display pre-copulatory behavior that consists of "holding" and "manipulating" females within their pereiopods, thus protecting them until they molt and mating can occur. In this respect, larger males would have greater mating success. However, it should be noted that only essentially aquatic species living in submersed environments show such pre-copulatory behavior during the females' ecdysis period. Intertidal crabs can mate in the intermolt period (HARTNOLL, 1969; PINHEIRO, 1993; BROCKERHOFF; MCLAY, 2005).

The presence of juvenile individuals throughout the year in the bays studied indicates that this species could reproduce continuously with recruitment periods from the beginning of the summer through into the winter.

According to Castro-Filho et al. (1987), during summer the southeastern Brazilian coast is strongly influenced by the South Atlantic Central Water (SACW) that brings a large quantity of nutrients to this region. This favors primary production (phytoplankton), which feeds large populations of zooplankton and could explain the intense recruitment in this period of the year. As mentioned by the same authors, this water mass reaches the northern coast of the state of São Paulo in the late spring.

Bertini et al. (2001) and Costa et al. (2005) noted that the effect of the SAWC was more intense during 1999, which favored the increase in the number of individuals in the samplings. Thus, the dynamics of the water mass could be the main factor determining the temporal distribution of the demographic groups of A. schmitti and cause the juvenile recruitment to last from summer to autumn.

It is obvious that further studies concerning benthic population structure are needed for a better comprehension of marine ecosystem dynamics, especially with respect to those species of no economic interest but high ecological importance. In this sense, there is a lack of published studies on $A$. schmitti. Additional investigations into this crab species could provide fundamental information for environmental management and conservation. 


\section{ACKNOWLEDGEMENTS}

The authors are grateful to the Fundação de Amparo à Pesquisa do Estado de São Paulo (FAPESP) for financing the field work (\#97/12106-3; \#97/121086 and $\# 97 / 12107-0$ ), to the NEBECC (Center of studies in Biology, Ecology and Cultivation of Crustacean) members for their help during the field work and to Prof. Dr. Gustavo Augusto dos Santos Melo for identification of specimens. All collections were accomplished in accordance with Brazilian state and federal laws concerning wild invertebrate sampling (Authorization number 007/98 of Instituto Brasileiro do Meio Ambiente e dos Recursos Naturais Renováveis - IBAMA).

\section{REFERENCES}

AB'SABER, A. N. Contribuição à geomorfologia do litoral paulista. Rev. Bras. Geogr., v. 17, n. 1, p. 3-48, 1955.

ALUNNO-BRUSCIA, M. B.; SAINT-MARINE, B. Abdomen allometry, ovary development, and growth of female snow crab, Chionoecetes opilio (Brachyura, Majidae), in the northwestern Gulf of St. Lawrence. Can. J. Fish. Aquat. Sci., v. 55, n. 2, p. 459-477, 1998.

ALVES, D. F. R.; BARROS-ALVES, S. P.; COBO, V. J.; LIMA, D. J. M.; FRANSOZO, A. Checklist of the brachyuran crabs (Crustacea: Decapoda) in the rocky subtidal zone of Vitória Archipelago, southeast coast of Brazil. Check List, v. 8, n. 5, p. 940-950, 2012.

BAEZA, J. A.; BRAGA, A. A.; LÓPEZ-GRECO, L. S.; PEREZ, E.; NEGREIROS-FRANSOZO, M. L.; FRANSOZO, A. Population dynamics, sex ratio and size at sex change in a protandric simultaneous hermaphrodite, the spiny shrimp Exhippolysmata oplophoroides. Mar. Biol., v. 157, n. 12, p. 2643-2653, 2010.

BENETTI, A. S.; NEGREIROS-FRANSOZO, M. L. Relative growth of Uca burgersi (Crustacea, Ocypodidae) from two mangroves in the southeastern Brazilian coast. Iheringia, Ser. Zool., v. 94, n. 1, p. 67-72, 2004.

BERTINI, G.; FRANSOZO, A. Bathymetric distribution of brachyuran crab (Crustacea, Decapoda) communities on coastal soft bottom off southeastern Brazil. Mar. Ecol.: Prog. Ser., v. 279, p. 193-200, 2004.

BERTINI, G.; FRANSOZO, A.; COSTA, R. C. Ecological distribution of three species of Persephona (Brachyura, Leucosiidae) in the Ubatuba region, São Paulo, Brazil. Nauplius, v. 9, n. 1 p. 31-42, 2001.

BERTINI, G.; FRANSOZO, A.; MELO, G. A. S. Biodiversity of brachyuran crabs (Crustacea: Decapoda) from non-consolidaded sublitoral bottom on the northern coast of São Paulo State, Brazil. Brazil. Biodiversity Conserv., v. 13, n. 12, p. 2185-2207, 2004.

BERTINI, G.; FRANSOZO, A.; NEGREIROS-FRANSOZO, M. L. Brachyuran soft-bottom assemblage from marine shallow waters in the southeastern Brazilian littoral. Mar. Biodiversity, v. 40, n. 4, p. 277-291, 2010.

BRAGA, A. A.; FRANSOZO, A.; BERTINI, G.; FUMIS, P. B. Bathymetric distribution and recruitment of the spider crab Libinia spinosa H. Milne Edwards 1834 in the
Ubatuba and Caraguatatuba regions, northern coast of São Paulo, Brazil (Crustacea, Brachyura, Majoidea, Pisidae). Senckenbergiana Biol., v. 87, n. 1, p. 7-16, 2007.

BRAGA, A. A.; FRANSOZO, A.; BERTINI, G.; FUMIS, P. B. Composition and abundance of the crabs (Decapoda, Brachyura) off Ubatuba and Caraguatatuba, northern coast of São Paulo, Brazil. Biota Neotrop., v. 5, n. 2, 2005.

BRANCO, J. O.; FRACASSO, H. A. A. Ocorrência e abundância da carcinofauna acompanhante na pesca do camarão sete-barbas Xiphopenaeus kroyeri Heller (Crustacea, Decapoda), na Armação do Itapocoroy, Penha, Santa Catarina, Brasil. Rev. Bras. Zool., v. 21, n. 2, p. 295-301, 2004.

BROCKERHOFF, A. M.; MCLAY, C. L. Mating behaviour, female receptivity and male-male competition in the intertidal crab Hemigrapsus sexdentatus (Brachyura: Grapsidae). Mar. Ecol.: Prog. Ser., v. 290, p. 179-191. 2005.

BUCHANAN, B. A.; STONER, A. W. Distributional patterns of blue crabs (Callinectes spp) in tropical estuarine lagoon. Estuaries, v. 11, n. 4, p. 231-239, 1988.

CASTIGLIONI, D. S.; NEGREIROS-FRANSOZO, M. L. Comparative population biology of Uca rapax (Smith, 1870) (Brachyura, Ocypodidae) from two subtropical mangrove habitats on the Brazilian coast. J. Nat. Hist., v. 39, n. 19, p. 1627-1640, 2005.

CASTRO-FILHO, B. M.; MIRANDA, L. B.; MIYAO, S. Y. Condições hidrográficas na plataforma continental ao largo de Ubatuba: variações sazonais e em média escala. Bol. Inst. Oceanogr., v. 35, n. 2, p. 135-151, 1987.

COELHO, P. A.; COELHO-FILHO, P. A. Taxonomia e distribuição dos Eucratopsinae pertencentes aos gêneros Eurytium, Cyrtoplax e Eurypanopeus (Crustacea, Decapoda, Xanthidae) do litoral brasileiro. Rev. Nord. Zool., v. 1, n. 1, p. 101-124, 1994.

COSTA, R. C.; FRANSOZO, A. Abundance and ecological distribution of the shrimp Rimapenaeus constrictus (Crustacea, Penaeidae) on the northern coast of São Paulo, Brazil. J. Nat. Hist., v. 38, n. 7, p. 901-912, 2004.

COSTA, R. C.; FRANSOZO, A.; CASTILHO, A. L.; FREIRE, F. A. M. Annual, seasonal and spatial variation of abundance of the shrimp Artemesia longinaris (Decapoda: Penaeoidea) in south-eastern Brazil. J. Mar. Biol. Assoc. U K., v. 85, n. 1, p. 107-112, 2005.

COSTA, R. C.; FRANSOZO, A.; FREIRE, F. A. M.; CASTILHO, A. L. Abundance and ecological distribution of the "sete barbas" shrimp Xiphopenaeus kroyeri (Heller, 1862) (Decapoda: Penaeoidea) in three bays of the Ubatuba region, southeastern Brazil. Gulf Carib. Res., v. 19, n. 1, p. 33-41, 2007.

COSTA, R. C.; FRANSOZO, A.; MANTELATTO, F. L. M.; CASTRO, R. H. Occurrence of shrimp species (Crustacea: Decapoda: Natantia: Penaeidea and Caridea) in Ubatuba Bay, Ubatuba, SP, Brazil. Proc. Biol. Soc. Washington, v. 113, n. 3, p. 776-781, 2000.

DE LÉO, F. C.; PIRES-VANIN, A. M. S. Benthic megafauna communities under the influence of the South Atlantic Central Water intrusion onto the Brazilian SE shelf: a comparison between an upwelling and a non-upwelling ecosystem. J. Mar. Syst., v. 60, n. 3/4, p. 268-284, 2006. 
DÍAZ, H.; CONDE, J. E. Population dynamics and life history of the mangrove crab Aratus pisonii (Brachyura, Grapsidae) in a marine environment. Bull. Mar. Sci., v. 45, n. 1, p. 148-163, 1989.

FRANSOZO, A.; MANTELATTO, F. L. M.; BERTINI, G.; FERNANDES-GÓES, L. C.; MARTINELLI, J. M. Distribution and assemblages of anomuran crustaceans in Ubatuba Bay, north coast of São Paulo State, Brazil. Acta Biol. Venez., v. 18, n. 4, p. 17-25, 1998.

FRANSOZO, A.; NEGREIROS-FRANSOZO, M. L.; MANTELATTO, F. L. M.; PINHEIRO, M. A. A.; SANTOS, S. Composição e distribuição dos Brachyura (Crustacea, Decapoda) do sublitoral não consolidado na Enseada da Fortaleza, Ubatuba (SP). Rev. Bras. Biol., v. 52, n. 4, p. 667-675, 1992.

FUMIS, P. B.; FRANSOZO, A.; BERTINI, G.; BRAGA, A. A. Morphometry of the crab Hexapanopeus schmitti (Decapoda: Xanthoidea) on the northern coast of the state of São Paulo, Brazil. Rev. Biol. Trop., v. 55, suppl. 1, p. 163-169, 2007.

HÅKANSON, L.; JANSSON, M. Principles of lake sedimentology. Berlin: New York: Springer-Verlag, $1983.315 \mathrm{p}$.

HALEY, S. R. Sex ratio as a function of size in Hippa pacifica Dana (Crustacea, Anomura, Hippidae): a test of the sex reversal and differential growth rate hypotheses. Am. Nat., v. 113, n. 3, p. 391-397, 1979.

HARTNOLL, R. G. Growth. In: BLISS, D. E. (Ed.). The biology of crustacea: embryology, morphology and genetics. 2. ed. New York: Academic Press, 1982. p. 11196.

HARTNOLL, R. G. Mating in the Brachyura. Crustaceana, v. 16, n. 2, p. 161-181. 1969.

HEBLING, N. J.; MANTELATTO, F. L. M.; NEGREIROSFRANSOZO, M. L.; FRANSOZO, A. Levantamento e distribuição de braquiúros e anomuros (Crustacea, Decapoda) dos sedimentos sublitorais da região da Ilha Anchieta, Ubatuba (SP). Bol. Inst. Pesca, v. 21, p. 1-9, 1994.

LAVRADO, H. P.; FALCÃO, A. P. C.; CARVALHOCUNHA, P.; SILVA, S. H. G. Composition and distribution of Decapoda from Guanabara Bay, RJ. Nauplius, v. 8, n. 1, p. 15-23, 2000.

MAHIQUES, M. M. Dinâmica sedimentar atual nas enseadas da região de Ubatuba, estado de São Paulo. Bol. Inst. Oceanogr., v. 43, n. 2, p. 111-122, 1995. MAHIQUES, M. M.; TESSLER, M. G.; FURTADO, V. V. Characterization of energy gradient in enclosed bays of Ubatuba region, south-eastern Brazil. Estuarine, Coastal Shelf Sci., v. 47, n. 4, p. 431-446, 1998.

MANTELATTO, F. M. L.; FRANSOZO, A. Brachyuran community in Ubatuba Bay, northern coast of São Paulo State, Brazil. J. Shellfish Res., v. 19, n. 2, p. 701-709, 2000.

MANTELATTO, F. L. M.; FRANSOZO, A. Characterization of the physical and chemical parameters of Ubatuba Bay, northern coast of São Paulo State, Brazil. Rev. Bras. Biol., v. 59, n. 1, p. 23-31, 1999a.

MANTELATTO, F. L. M.; FRANSOZO, A. Reproductive biology and moulting cycle of the crab Callinectes ornatus (Decapoda, Porunidae) from the Ubatuba region, São Paulo, Brazil. Crustaceana, v. 72, n. 1, p. 63-76, 1999b.
MANTELATTO, F. L. M.; FRANSOZO, A.; NEGREIROSFRANSOZO, M. L. Distribuição do caranguejo Hepatus pudibundus (Herbst, 1785) (Crustacea, Decapoda, Brachyura) na Enseada de Fortaleza, Ubatuba (SP), Brasil. Bol. Inst. Oceanogr., v. 43, n. 1, p. 51-61, 1995a.

MANTELATTO, F. L. M.; FRANSOZO, A.; NEGREIROSFRANSOZO, M. L. Population-structure of Hepatuspudibundus (Decapoda, Calappidae) in Forataleza Bay, Brazil. Rev. Biol. Trop., v. 43, n. 1/3, p. 265-270, 1995b.

MELO, G. A. S. Manual de identificação dos Brachyura (caranguejos e siris) do litoral brasileiro. São Paulo: Plêiade: FAPESP, 1996. 604 p.

NEGREIROS-FRANSOZO, M. L.; FRANSOZO, A.; PINHEIRO, M. A. A.; MENTELATTO, F. L. M.; SANTOS, S. Caracterização física e química da Enseada de Fortaleza, Ubatuba, SP. Rev. Bras. Geocienc., v. 21, n. 2, p. 114-120, 1991.

NEGREIROS-FRANSOZO, M. L.; FRANSOZO. A.; MANTELATTO, F. L. M.; PINHEIRO, M. A. A.; SANTOS, S. Anomura species (Crustacea, Decapoda) and their ecological distribution at Fortaleza Bay sublitoral, Ubatuba, São Paulo, Brazil. Iheringia, Ser. Zool., v. 83, p. 187-194, 1997.

NEGREIROS-FRANSOZO, M. L.; NAKAGAKI, J. M. Differential benthic occupation by crabs in the Ubatuba Bay, São Paulo, Brazil. J. Shellfish Res., v. 17, n. 1, p. 293-297, 1998.

NEGREIROS-FRANSOZO, M. L; NAKAGAKI, J. M.; REIGADA, A. L. D. Seasonal occurrence of decapods in shallow waters of a subtropical area. In: KLEIN, J. C. V. V.; SCHRAM, F. R. (Eds.). The biodiversity crisis and crustácea. Rotterdam: A. A. Balkema, 1999. p.351-361. (Crustacean Issues; 12) [Proceedings of the Fourth International Crustacean Congress, Amsterdam, Netherlands, 20-24 July 1998].

NEGREIROS-FRANSOZO, M. L.; REIGADA, A. L. D.; FRANSOZO, A. Braquiúros (Crustacea, Decapoda) dos sedimentos sublitorais da Praia da Enseada, Ubatuba (SP). Bol. Inst. Pesca, v. 19, p. 17-22, 1992.

ODEBRECHT, C.; CASTELlO, J. P. The convergence ecosystem in the southwest Atlantic. In: SEELIGER, U.; KJERFVE, B. (Eds.). Coastal marine ecosystem of Latin America. Berlin: Heidelberg: Springer-Verlag, 2001. 360 p. (Ecological Studies; v. 144).

PINHEIRO, M. A. A. Comportamento copulatório de Panopeus rugosus A. M. Edwards, 1880 (Crustacea, Brachyura, Xanthidae) em cativeiro. Biotemas, v. 6, n. 1, p. 115-120, 1993.

PIRES-VANIN, A. M. S. Structure and dynamics of benthic megafauna on the continental shelf offshore of Ubatuba, Southeastern Brazil. Mar. Ecol.: Prog. Ser., v. 86, p. 63-76, 1992.

PIRES-VANIN, A. M. S.; MATSUURA, Y. Estrutura e função do ecossistema de plataforma continental da região de Ubatuba, Estado de São Paulo: uma introdução. Publ. Espec. Inst. Oceanogr., v. 10, p. 1-8, 1993.

RUFFINO, M. L.; CASTELlO, J. P. Alterações na ictiofauna acompanhante da pesca do camarão-barbaruça (Artemesia longinaris) nas imediações da Barra de Rio Grande, Rio Grande do Sul - Brasil. Nerítica, v. 7, n. $1 / 2$, p. $43-55,1992 / 1993$. 
SHIRLEY, M. A., HINES, A. H.; WOLCOTT, T. G. Adaptive significance of habitat selection by molting adult blue crabs Callinectes sapidus (Rathbun) within a subestuary of central Chesapeake Bay. J. Exp. Mar. Biol. Ecol., v. 140, n. 1/2, p. 107-119, 1990.

SUGUIO, K. Introdução a sedimentologia. São Paulo: Edgard Blucher, 1973. $317 \mathrm{p}$

SUMIDA, P. Y. G.; PIRES-VANIN, A. M. S. Benthic associations of the shelfbreak and upper slope off Ubatuba-SP, South-eastern Brazil. Estuarine, Coastal Shelf Sci., v. 44, n. 6, p. 779-784, 1997.

TUCKER, M. (Ed.). Techniques in sedimentology. Oxford: Boston: Blackwell Scientific Publications, 1988. 394 p.

WENNER, A. M. Sex ratio as a function of size in marine crustacea. Am. Nat., v. 106, n. 948, p. 321-350, 1972.

WENTWORTH, C. K. A scale of grade and class terms for clastic sediments. J. Geol., v. 30, n. 5, p. 377-392, 1922.

WILSON, K.; HARDY, I. C. W. Statistical analysis of sex ratios: an introduction. In: HARDY, I. C. W. (Ed.). Sex ratios: concepts and research methods. Cambridge: Cambridge University Press, 2002. p. 48-92.
WINGET, R. R.; MAURER, D.; SEYMOUR, H. Occurrence, size composition and sex ratio of the rock crab, Cancer irroratus say and the spider crab, Libinia emarginata Leach in Delaware Bay. J. Nat. Hist., v. 8, n. 2, p. 199-205, 1974

ZAR, J. H. Biostatistical analysis. 3. ed. Upper Saddle River: Prentice-Hall, 1996. 918 p.

(Manuscript received 06 March 2013; revised 01 December 2013; accepted 09 December 2013) 